\title{
O Rural no urbano: uma análise do processo de produção do espaço de Imperatriz - MA
}

\author{
Rosirene Martins LIMA
}

Dissertação de Mestrado: Curso de Mestrado em Geografia - UFPR

Data da defesa: 20 mar. 2003

Banca:

Francisco de Assis Mendonça

Júlio César Suzuki

Saint Clair Cordeiro Trindade Júnior

\section{RESUMO}

A cidade de Imperatriz, no estado do Maranhão, se por um lado possui status de "cidade grande", considerando-a em relação à maioria das cidades da Amazônia, por outro apresenta características rurais, em termos de sua paisagem e também de sua própria dinâmica. A investigação de tal realidade partiu da necessidade de compreender sua dinâmica interna, que mescla situações tidas como rurais e urbanas no seu conjunto, produzindo um espaço diverso, multiforme. Para tanto, adotaram-se como procedimentos para a pesquisa a busca de fontes secundárias sobre a cidade, observação direta e entrevistas abertas com tra- balhadores rurais e suas famílias, que, a despeito de morarem na cidade, vivem como se estivessem na área rural, exercendo atividades agrícolas e extrativas. Frente aos dados coletados no período da pesquisa de campo e frente aos resultados das entrevistas foi possível questionar a distinção entre rural e urbano, ou ainda analisar o urbano como fator hegemônico nesta realidade empírica, denominada Imperatriz.

Palavras-chave:

Imperatriz, rural, urbano, trabalhadores rurais. 